\title{
Skills Development: A RevieW With REFERENCE To SOUTHEAST Asia
}

\author{
Jane Parry \\ International Development Consultant \\ Martin Hayden \\ Southern Cross University
}

\begin{abstract}
In a context of rapid economic growth, skills development systems have become increasingly important to countries in Southeast Asia in response to skills gaps generated by changing labour-market conditions. Countries in the region have no alternative but to invest in the development and maintenance of these systems. This paper asserts that in doing so they should recognise the importance of adopting a definition of skills that encompasses cognitive and soft skills as well as technical skills, they should regard as being essential to the development of effective labour market information systems, and they should adopt and institutional frameworks that are adequate to the task of managing complex and effective national skills development systems.
\end{abstract}

KEYWORDS: Skills development, Southeast Asia, skills gaps, labour markets, labour market policies, ASEAN.

\section{Introduction}

Over recent years, skills development has emerged as a topic of increasing interest to academics, policy makers and economists alike. This growth of interest has been prompted by a global surge in youth unemployment rates following the Global Financial Crisis of 2008-09. It reflects also a commitment to the view that skills development will help alleviate the problem of high youth unemployment levels. Various international agencies, including the Organisation for Economic Cooperation and Development (OECD) (2012a, 2014a), the United Nations Educational, Scientific and Cultural Organization (UNESCO) (2012), the International Labour Organization (ILO) (2012, 2014a), McKinsey Global Institute (2012) and the World Bank (2013a), have reported on the matter.

This paper discusses the importance of skills development in the Southeast Asian region, defined as those nations belonging to ASEAN (the Association of Southeast Asian Nations). The ASEAN region is experiencing both a high level of youth unemployment, projected to be $13.6 \%$ in 2015 (ILO 2015, Table 2.7), and significant skills shortages. For most ASEAN nations, the structural shift away from agricultural activities towards industry, services and knowledge activities is continuing and gives rise to a growing need for new or different skills in the workforce (ILO 2015, p.47). To meet this need, and to maintain economic growth, these nations have to attend more to the quality of their skills development systems. ASEAN as a region is becoming increasingly significant as a global economic entity (Naidu-Ghelani, 2015), but individual member states vary greatly in their level of economic development and rate of economic transition, and their capacity to respond to structural labour market changes and to supply the skills required has been mixed.

\section{Skills, Skills Problems and Approaches to Skills Development}

In describing skills and skills-related problems, some existing conceptual frameworks and definitions first need to be briefly outlined. Across the skills development literature, there is a tendency to focus

\footnotetext{
a Correspondence can be directed to: janeparry.jp@gmail.com
} 
mainly on technical skills as the most immediate solution for the resolution of skills shortages in an economy. In the context of economic development, however, a more holistic understanding of the nature of skills is warranted, including three categories of skills. These are: cognitive skills, that is, skills and capacities of a cognitive nature that are acquired primarily through participation in formal education; technical skills, known as skills and capacities of a manual or procedural nature that are acquired mainly through pre-employment vocational training programmes delivered by technical and vocational education (TVET) institutions and the like; and soft skills, described as skills and capacities concerning interpersonal communications, leadership, management ability and empathy that are acquired in part through participation in formal education but which may also inculcated in the home.

These skills categories need to be considered in relation to three common types of skills problems. As identified by Capelli $(2015$, p.252), these are: skills gaps, which occur when an education system does not adequately equip a nation's young people with the skills required by the labour market; skills shortages, which occur when there are shortfalls in particular skill categories within a nation's labour market; and skills mismatches, which occur when the skills of employees are not well aligned with the skills required by their jobs, resulting in either over-skilling or under-skilling in the labour market. Skills gaps and skills shortages tend to be the most commonly reported types of skills problems in the Southeast Asian region, while skills mismatches are less frequently reported in the literature from the region.

A range of conceptual perspectives exists in skills development discourse. In the standard neoclassical labour-market approach, skills development is a process that occurs naturally in response to price signals from the labour market: other things being equal, an increase in the wage rate in a particular skills area will attract more people to undertake the skills development required to access the jobs offering the higher wage rate. This perspective is helpful in isolating key drivers of skills development, but it rests on assumptions about perfect market information, the unrestricted mobility of labour and rational economic decision making that are rarely found in practice.

Another economic approach is one that sees skills development from the perspective of human capital theory. From this perspective, skills development is fundamental to economic growth and development because it provides a foundation of skills for the more efficient functioning of industry and for the more effective utilisation of productivity-enhancing technologies. This perspective appears to be well supported by evidence. From an extensive review of the relevant literature, Rodrik (2013, p.4) concluded that the accumulation of human capabilities in the form of human capital is significant in contributing to economic growth and development. As Rodrik notes, though, a more important influence on economic development is structural transformation in the form of a transition from a dependency on primary industry to a greater reliance on manufacturing and service industries.

More comprehensive in nature than either of the economic approaches is a model of skills development proposed by the World Bank and referred to as the Skills Toward Employment and Productivity (STEP) model (World Bank, 2010). This model identifies the following five stages for skills development: getting children off to the right start - where the focus is on health and the development of cognitive and soft skills; laying a strong foundation in basic education - where the focus is on the development of cognitive and soft skills; building job-relevant skills that employers demand - where the focus is on the development of technical skills; encouraging innovation and entrepreneurship - where the focus is on the effective deployment of skills in the economy; and matching skills demand and supply - where the focus is on the effective utilisation of available skills in the economy.

The World Bank proposed that its model should be utilised to undertake country-level studies of the formation of cognitive, technical and non-cognitive skills, as well as of the extent to which mismatches between skills availability and employer needs may be occurring. To date, however, only one such study has been conducted in the Southeast Asian region. It concerned Vietnam (World Bank, 2014a) and it identified a general need for Vietnam to invest more heavily in the promotion of early childhood development, the cultivation of foundational cognitive and behavioural skills, and the development of job-relevant technical skills. The study also found that better connections 
were needed between firms, universities and technical colleges so that programmes of study could be better attuned to the needs of the labour market and so that students could be better informed about employment opportunities.

The World Bank approach, using the STEP model, is more holistic in nature than any of the economic models. It is also, however, a model that requires the collection of a significant volume of data if it is to be fully deployed for the purposes of examining the skills development environment in a particular economy. A drawback of the model in the context of Southeast Asia is that at least one-half of the countries in the region do not have a well-developed information base to support the deployment of the model. In order to implement such systems in Southeast Asia, these nations would require significant external investments from agencies such as the World Bank.

\section{Beyond Technical Skills}

Much of the literature on skills development in Southeast Asia, and more broadly in Asia (see for example, OECD, 2012b), focuses on the importance of developing vocational and technical skills. Indeed, in a review of skills development pathways in Asia, Martinez-Fernandez and Choi $(2012$, p.26) observe that expanding vocational education at the secondary education level is "one of the key elements in skills development strategies in Asian countries." This situation is not surprising, given the pace of structural transformation in most Asian economies and the associated need for more and better-trained technical personnel, but technical skills alone are an inadequate preparation for job readiness. Across many Southeast Asian nations, the cognitive skills of young people leaving school to enter the labour force or to undertake technical training are not particularly well developed. The problem is most acute in the region's poorer nations, such as Cambodia, Laos and Myanmar, but is also evident among poor communities living in many of the better-developed nations, such as Vietnam, the Philippines, Indonesia and Thailand. Laos provides an example of the problem. A survey of reading skills in Laos found that $30 \%$ of children in the second grade of school could not read a single word (World Bank 2014b, p.12). The reading skills of students completing secondary-level programmes were also found in the same survey to be equivalent to those of children completing primary school in Vietnam.

Cognitive skills provide an important foundation for national prosperity. Even a small national improvement in these skills can greatly improve employment prospects for young people and raise the value of gross national production (Hanushek and Woessmann, 2015). Establishing high threshold levels of cognitive skills is in the interests of all ASEAN countries, as it is in the case of China, where it has been estimated that: "Labour productivity would be $23 \%$ higher if junior high-school graduates had senior high-school education and would double if senior high-school graduates had college training" (Molnar and Koen 2015, p.9). As a recent World Bank report on Laos concluded, neglecting cognitive skills is costly for a nation: "Basic literacy (or lack thereof) has real implications for economic growth" (World Bank 2014b, p.51).

Opportunities to compare the performance of different Southeast Asian nations regarding the cognitive skills attainments of their young people are limited because of the absence of relevant comparative data. Only five Southeast Asian nations participated in the international Programme for International Assessment (PISA) survey conducted across 63 countries and regions in 2012. PISA tested levels of mathematical, scientific and reading literacy among 15-year-olds. Singapore and Vietnam achieved results that were significantly above the OECD average, while Thailand, Malaysia and Indonesia achieved results that fell well below the OECD average. Indeed, young Indonesian participants scored so poorly, on average, that many were considered unlikely to be able to remain in school beyond the minimum leaving age (OECD 2014b, p.9). This situation greatly diminishes Indonesia's capacity to respond to skills gaps. It also places the young people concerned at an enormous disadvantage internationally in the competition for jobs. Low national average cognitive skill levels mean that many young people may be several school years behind children in the same age group attending school in other countries. It has been estimated that the gap, on average, 
between children from Indonesia and children from any of Korea, Hong Kong or Singapore may be at least three school years (OECD and ADB 2015, p.19).

Technical skills are, without doubt, important as a foundation for employment, but their importance must be seen in the context of a broader definition of skills that also takes account of cognitive and soft skills. Marked variations across the ASEAN region are evident in terms of how effectively and successfully technical skills are developed, but firm comparative data in this regard are limited in terms of quality and availability. Singapore is, without much doubt, the leader in terms of technical skills development - as it appears also to be in terms of cognitive skills development. Its achievements in this regard are widely acknowledged (see for example, World Bank 2012a, p.16). Singapore enrols about $25 \%$ of the relevant age cohort each year in its national Institute of Technical Education (ITE), a network of colleges offering career-based vocational training that leads to technician-level employment in the fields of engineering, Information and Communications Technology (ICT), health sciences, business and business services. The ITE is successful for many reasons. It is well funded by the State; its programmes are popular and well delivered; there is a mix of classroom-based and experiential learning; pathways exist to enable graduates from its programmes to proceed to a polytechnic for higher-level training; industry partners play a significant role in identifying the skill needs to be addressed in the curriculum; and high employment rates are achieved by ITE graduates.

Other nations in the ASEAN region now face challenges with the development of technical skills that Singapore overcame during the 1990s when it began to reconstruct its TVET system. These challenges include: integrating enterprise-based training with training provided formally in classrooms; increasing the relevance of technical training programmes in terms of industry needs; improving the quality of teaching skills in TVET colleges; and raising the standard of leadership and management in TVET institutions (ADB 2014, pp. 61-62; see also Maclean, Jagannathan and Sarvi 2013, pp.9-19). On-the-job training, and participation in the non-formal education sector, also need to be properly integrated with formal programmes of technical skills development. These are important additional forms of technical skills development in Southeast Asia, but most countries in the region have not yet developed procedures for giving formal recognition for skills acquired by means of on-the-job training and non-formal education.

The extent of the need across Southeast Asia for more young people to acquire technical skills is not to be underestimated. Data on the matter are, however, difficult to locate. From Vietnam, though, it is reported that in 2011 only $15.2 \%$ of the 50.4 million people in the workforce had received any form of technical training, and only $3.7 \%$ of the total workforce had acquired any formal technical qualifications (World Bank 2012b, p.9).

Soft skills, including skills in communication, teamwork, problem solving, enterprise, planning and organising, self-management, lifelong learning and the use of technologies, are very important to employers. This is evident in literature from Southeast Asia (see for example, ADB, 2012a; World Bank, 2012b), as well as globally (see for example, World Economic Forum 2014, p.10). Measuring soft skills, and explaining why they are so important, are, however, matters that have not been easy to address systematically because of the wide range of soft skills typically referred to by employers, and because the reasons employers give for the importance of these skills are often extremely varied. To be effective, however, skills development systems must give attention to the importance of these skills.

Recent findings reported by the OECD are noteworthy here. Drawing particularly on research about the nature of 'character' by Heckman and colleagues (Heckman, Stixrud and Urzua, 2006; Heckman and Kautz, 2013), and with the development of a 'social and emotional skills' construct, OECD research is showing that soft skills, defined as a composite of elements that include conscientiousness, openness to new experience, self-efficacy, social communication, team-working skills, agreeableness and emotional stability, do impact both directly and indirectly on labour-market outcomes (OECD 2015, p.69). The OECD research suggests that the best way in which schools, colleges and universities can assist young people to develop 'social and emotional skills' is by including the 
measurement of their successful acquisition in the normal student assessment processes. The kinds of assessment tasks that are more likely to indicate the attainment of these skills may be those that are 'authentic' in nature, requiring perhaps students to produce portfolios to demonstrate their learning. To date, however, it is evident that there are relatively few education systems that have explicitly built consideration of these skills into their student assessment frameworks (OECD 2015, pp.95-109).

In summary, it is important to consider cognitive, technical and soft skills in combination when establishing a skills development system. A national skills development system that focuses too narrowly on the development of technical skills is at risk of overlooking the labour-market importance of cognitive and soft skills.

\section{Effective Information Systems}

The literature on skills development widely acknowledges that effective skills development systems are those that respond efficiently and effectively to local needs. As Martinez-Fernandez and Weyman (2014, p.262) report, while international lessons on how to develop skills are useful, "targeted strategies need to match the conditions in each country, which are not uniform across Asian economies". According to UNESCO (2012, p.30), relevant skills should be generated by training that is "adapted to each local context, filling clear gaps in the skills base in the local area." To achieve such localised systems, there is a need for national information management systems capable of informing stakeholders about contextual factors, forecasting future labour-market needs, and enabling lessons to be learnt for past successes and failures.

Without an effective labour-market information system, a skills development system lacks the capacity to report quantifiable achievements, such as participation rates, unemployment rates, and graduation rates. Neither is it able to describe or address the underlying causes of skills gaps; nor quantify the impact that social factors such as poverty may be having in limiting access to skills development strategies. For prospective students, policy makers, industry stakeholders, employers and training providers, the absence of adequate information can result in skills development systems that fail to provide relevant skills and that are unable to alleviate skills gaps. In Vietnam, for example, young people were found to need better labour-market information, more information about graduate job placements, and more transparency regarding occupational competency standards and certification systems (World Bank 2014a, p.9). The World Bank has similarly reported that “Lao PDR's vocational education system does not seem to be as responsive as it needs to be and suffers from 'disconnects' among the schools, employers, and students... No formal mechanisms are available for firms to provide feedback to schools on their programmes or quality of teaching" (World Bank 2014b, p.60). In Myanmar, the ILO found that "the data is often limited, the definitions of TVET programmes are not fully clarified, the standards are constrained, and the [data collection and storage] equipment is obsolete" (ILO 2014b, p.5), and that a "major obstacle to understanding the [TVET] development challenges in Myanmar is the lack of accurate and consistent data" (ILO 2014b, p.6).

In emerging economies, the growth in importance of the informal labour market can further confound the collection of accurate labour market data, making sound interpretations about emerging needs extremely challenging. Though this sector of the labour market, which comprises highly adaptive enterprises, makes a vital contribution to skills demand in the countries concerned, it is a contribution that remains largely beyond the reach of existing labour-market data collection mechanisms and information systems. Detailed analyses of skills needs for the informal sectors in Africa have been undertaken (such as those discussed in UNESCO, 2011), but little evidence exists of these kinds of investigations having taken place in the Southeast Asian region. Without sufficient information on the informal sector and its skills needs, ASEAN nations may experience lags in responding appropriately to emerging skills gaps - and, as argued by Chen, Mourshed and Grant (2013) in the context of China, lags in responding to emerging skills gaps can be costly for a nation. 
A recent development of note for its importance in directing attention to a comprehensive and consistent set of indicators for appraising national technical skills development systems is the World Bank's focus on workplace development processes within the framework of its Systems Approach for Better Education Results (SABER) initiative, launched in 2014 (World Bank, 2014c). The SABER framework for workforce development examines the success of individual nations in terms of their strategic framework, system oversight and service delivery regarding technical skills development to meet labour-market needs. The indicators for which information must be obtained are: (a) articulating a strategic direction; (b) prioritising a demand-led approach; (c) strengthening critical coordination; (d) diversifying pathways for skills acquisition; (e) ensuring efficiency and equity in funding; (f) assuring relevant and reliable standards; (g) fostering relevance in training programmes; (h) incentivising excellence in training provision; and (i) enhancing accountability for results.

SABER country reports on workforce development have, to date, been produced for 25 countries, including three in Southeast Asia: Singapore, Malaysia and Vietnam (World Bank, 2012a, $2012 \mathrm{~b}$ and $2013 \mathrm{~b}$ respectively). The three reports completed on Southeast Asian countries point to some marked differences between workforce development processes and policies. Singapore received the highest rating across all three workforce development categories, with its strategic framework, system oversight and service delivery all considered 'advanced. Malaysia scored a lower overall rating of 'established', while Vietnam received the overall rating of 'emerging'. Singapore was described as having "a clear and coherent [workforce development] system with a highly developed policy and institutional framework" (World Bank 2012a, p.13). Malaysia was said to have "demonstrated considerable strength in formulating a strategic vision for [workforce development] and policies and institutions to support that vision, but its capability is weaker at the oversight and implementation levels" (World Bank 2013b, p.13). Vietnam was said to be "on the right track with its policies and institutions for [workplace development]. However, critical gaps remain between the demand for and supply of skilled and qualified workforce" (World Bank 2012b, p.14). Importantly, Singapore has an advanced labour market information system that underpins the quality of its performance.

The potential value of the SABER approach is significant, but some limitations of the process do need to be acknowledged. First, it will be of limited value if not repeated regularly. Given the pace of economic growth in the Southeast Asian region, the value of a profile that is two or three years old will decline rapidly. Second, it is a highly interpretive process, requiring expert panel members to rate different aspects of national workforce development systems by drawing upon secondary documentation and personal knowledge of a system. Though implemented in a way that tries to reduce the risk of bias, an appraisal process of this nature is not immune from human error, nor is it completely free from the need to be politically sensitive. Third, participation in the SABER process is voluntary. Only three Southeast Asian nations elected to have their workplace development systems reviewed. The reasons why these nations did elect to have their systems reviewed, and why other Southeast Asian nations did not elect to have their workplace development systems reviewed, reflect inconsistent levels of government commitment to skills development and the establishment of accountable, transparent TVET oversight. The reasons for limited engagement with the SABER workforce development review in Southeast Asian nations warrant further investigation.

As is evident from the SABER reviews of workforce development processes in Singapore, Malaysia and Vietnam, a capacity to collect, analyse and report labour-market data is critical in terms of the effective functioning of a national skills development system. For a number of ASEAN members, however, this capacity is weak. Vietnam's labour-market information system, for example, has been shown in several unrelated reports to have significant deficiencies (ADB, 2014; World Bank, 2014a). Though reports are not available on the labour-market information systems in Cambodia, Laos and Myanmar, these countries are even less developed than Vietnam and are, therefore, even less able to be able to maintain effective labour-market information systems.

In summary, effective skills development systems, like labour-market needs, are dynamic. They are, therefore, inherently dependent upon the effectiveness of communications between 
employers, industry and education providers regarding skills needs and emerging skills problems. This communication requires sophisticated national information systems for collecting and analysing information, as well as for disseminating key messages to stakeholders.

\section{Effective Policy Settings}

As this paper has discussed, skills systems are highly complex and locally specific. In order to effectively respond to the labour market and adapt to changing patterns of skills demand, they require sustained policy commitment, coordinated administration and adequate funding. As the World Bank has observed: "Accountability and governance arrangements are often the weak link of skills-building initiatives, with institutional failures often replacing market failures" (World Bank 2013a, p.176). Across ASEAN nations, however, the capacity of governments to manage these elements has been mixed.

For less developed nations, particularly those that have experienced rapid economic growth, the problem is most acute. A review of the TVET system in Vietnam reported, for example, that:

...the existing fragmentation and complexity of institutional ownership and governance complicates policy implementation, including efforts to improve the effectiveness of skills acquisition... As a consequence of the organizational fragmentation, no one has an overview of all skills development ... Fragmentation of state management of TVET is the main reason for poor coordination in TVET activities (ADB 2014, p.62).

A review of TVET in Myanmar similarly noted that:

...there is a lack of coordination among the ministries and their TVET providers, which results in either a lower quality of formal TVET delivery, or a lack of offers in some areas, causing confusion for young people trying to choose a career, or even for adults trying to get a (re) qualification (ILO 2014b, p.xii).

These examples contrast with Singapore, which is described as having an adaptive and highly effective system:

The system's effectiveness in delivering demand-led skills has been enabled by the close tripartite partnership between government, union and stakeholders, and a coordinated approach within government... The results from the SABER-WfD Benchmarking process highlight that Singapore made continuous progress and significant improvements in its workforce development (WfD) system from 1970 to 2010. This has created a clear and coherent system with highly a developed policy and institutional framework. It continues to be subject to review and enhancements, where needed, to respond to shifting policy challenges and economic demands (World Bank 2012a, p.3, p.13).

Each of these examples demonstrates a strong correlation between clear policy commitment and administrative capacity and the success of skills development systems.

Linked to policy commitment is the tendency of vocational education streams to be regarded as being inferior to academic education streams. This tendency is reported in literature on skills development across many countries in Southeast Asia, including Malaysia (World Bank 2013b, p.12), Myanmar (ILO 2014b, p.49), Indonesia (OECD and ADB 2015, p.35) and Cambodia (ADB 2012a, p.100). The poor esteem of vocational training seems to be related to a tradition of inconsistent government support for the development of appropriately regulated, nationally coordinated skills development systems. As a result, there may be poor teacher quality (ADB 2014, p.30), inadequate quality assurance mechanisms for courses (ADB 2012b, p.2; ILO 2014b, p.xii), and a supply-driven approach to providing training opportunities in the TVET system (ILO 2014b, p.xi; World Bank 
2014a, p.60). These circumstances further erode the reputation of TVET and its desirability for job-preparedness, public funding and prospective students, despite its potential to mitigate youth unemployment and skills shortages.

In response to the rapid growth of skills development and skills training, National Qualification Frameworks (NQFs) have become an increasingly popular policy response to poor coordination and inadequate oversight in Southeast Asia. Over recent years, all of the ASEAN member states have adopted various types of NQFs. An ASEAN Qualification Reference Framework (AQRF) has also recently been established for the purposes of providing a common reference framework for ASEAN member states, as well as to provide a basis for comparing the qualifications of skilled labour across the ASEAN region (ASEAN, 2014).

UNESCO has strongly advocated the development of national qualifications frameworks as a way of bringing coherence and clarity to tertiary education systems. Qualifications frameworks also bring together qualifications issued by different bodies on the basis of different levels of learning outcomes, and they provide a common frame of reference across countries, thereby assisting labour mobility (UNESCO, 2013). The success of NQFs in the Asian region has, however, been mixed. To be effective, they require a high level of administrative capacity to ensure accountability, quality, and mutually beneficial industry partnerships. As the World Bank has concluded, "Over 100 countries have embarked on comprehensive National Qualification Frameworks, built around the definition of competencies, certification, and accreditation. But with exceptions, results and impact are sobering" (World Bank 2013a, p.177). National qualifications frameworks can provide quality assurance and accountability frameworks that substantially improve the effectiveness and efficiency of public investment in education, but their development and implementation needs to be well resourced, and there is also a need for an adequate infrastructure and management capacity.

The provision of appropriate funding is also critical to the success of skills development systems. Singapore is an example from within the ASEAN region of a nation that has been prepared to invest strongly in the establishment and maintenance of an effective skills development system. Singapore's government has also been highly effective in securing industry investment in the national skills development system. As reported in the SABER evaluation of Singapore's workforce development processes, public funding of education in Singapore is high, coming second only to spending on defence, and an employer levy to pay for lifelong access to opportunities for job-related skills upgrading and retraining has been successfully implemented (World Bank, 2012a).

In the case of less developed Southeast Asian nations, a considerable portion of financial support for skills development is derived from international development assistance and private industry. Examples of this support include an Alcoa-funded Youth Development Program in Brunei, an ADB-funded Strengthening Technical and Vocational Education and Training Project in Cambodia, ILOfunded Education and Skills Training for Youth and Job Opportunities for Youth projects in Indonesia, an Australian-funded education and skills development programme in Laos, an ADB-funded Technical Education and Skills Development Project in the Philippines, and a GIZ-funded Regional Leadership and Capacity Development in TVET project in Indonesia, Laos and Vietnam. The breadth of external funding indicates that many of these nations do not yet have the internal financial or institutional capacity to sustainably support their skills development systems.

Many Southeast Asian nations also lack the financial management capacity to ensure that investment in skills development is adequate, efficient and effective. Poor budgetary and financial management are commonly reported, including the allocation of resources not linked to performance but to increases in enrolments, regardless of skills demand (ADB 2014, pp.63-64). Significant duplication of effort is also evident, with various ministries developing separate strategies and plans, and no central point of review or authority with access to national reporting from all TVET related government departments (ADB 2014, p.64; ILO 2014b, p.xi). Even where public funding for skills development is considerable, poor institutional capacity and coordination can undermine the efficacy of increased funding. 
Further complicating the problems of poor coordination is the rapid proliferation of private providers, who can quickly become difficult for public systems to regulate. The topic of private provision of technical skills development programmes in Southeast Asia is not well addressed in the literature. From literature on South Asia, however, it is reported that the private sector is now responsible for up to 75\% of TVET training, focussing on a "narrow band of occupations" (Panth 2014, p.174), the implication being that private providers may be responding primarily to market demand for particular skills, rather than working in collaboration with public providers towards the attainment of broader national skills outcomes. In general, private skills development providers in Southeast Asia are lightly regulated and audited, and it should be of concern that there seems to be little or no data available about their quality and performance. The risks of inadequately regulated private skills development providers are significant for students, national governments and employers.

Partnerships between private industry and government can, however, reap significant benefits if effectively managed. Hong Kong's strategy in developing its TVET sector was to partner with private industry to meet a shared skills development goal and to avoid duplication of investment. Hong Kong sought to ensure that public investment occurred in skills development areas of strategic importance to the economy that the private sector was less likely to support (Maclean, Jagannathan and Sarvi 2013, p.11). For programmes of study for which there was a high economic need but also a high capital investment cost, the State also subsidised tuition fees. In various parts of Southeast Asia, successful government partnerships with private industry are known to exist, as with Intel in Vietnam, but the details and impact of these partnerships are not well documented, limiting the likelihood that their success can be duplicated elsewhere.

Beyond funding, regulation and institutional capacity, skills development frameworks in Southeast Asian nations also need to respond to social and financial barriers limiting access to tertiary education. Social support mechanisms in Southeast Asian nations are generally weak, and vulnerable and disadvantaged populations are limited in their capacity to access skills programmes which may improve their earning capacity and ability to fill skills gaps. The ILO has observed that: "development should be viewed holistically as the productive transformation of the entire economy and labour market" (ILO 2014a, p.66).

Policy commitments and adequate funding, need therefore, to be accompanied by broader social measures and the attainment of social agency for marginalised and disadvantaged populations, including women, people with disabilities, marginalised populations, those living in poverty and in rural areas. Recent research also shows that effective social measures can "stimulate investment in skills formation" and these measures are reported as being increasingly included in the design and objectives of skills development programmes, providing an increased incentive for participation by marginalised and disadvantaged groups (ILO 2014a, p.132). Further arguments espouse that the most successful and lasting skills programmes act as holistic development solutions where "skills formation systems cannot only be designed to satisfy the needs of the economic systems, but also to satisfy wider basic needs of individuals and their communities" and to "develop the "agency freedom' of individuals" (Valiente 2014, p.46).

\section{Concluding Remarks}

This paper has discussed the importance of developing cognitive and soft skills as well as technical skills, creating effective information systems, and establishing institutional and regulatory framework for the coordination of skills development systems. Southeast Asian economies are experiencing unprecedented economic growth following structural transition from reliance on agriculture towards becoming service-oriented and knowledge based economies. They are now also beginning to reap the benefits of investments in skills development systems, though there is wide variation in the effectiveness and yield of the systems that have been developed. Over time, however, and as has already happened in the case of Singapore, their skills development systems will become central to continuing growth and prosperity. It is timely that all of the ASEAN Member States address the 
architecture for their skills development systems with a view to addressing current and future skills gaps.

Skills development systems in the region will be most effective where they are able to identify and track skills demand through effective data collection and analysis systems, and where they foster training programmes which build cognitive and soft skills as well as technical skills that best equip graduates to innovate and adapt to dynamic work environments. These systems must also have a capacity to be responsive to change, and to be informed by stakeholder needs and experiences. National governments will continue to have a vital role to play in coordinating and regulating national skills development systems to reduce duplication and maximise efficiency and effectiveness.

Across Southeast Asia, mechanisms to measure and improve the quality of skills development systems will be critical in ensuring that nations are able to respond to the skills needs of rapidly expanding and transitioning economies.

\section{References}

Asian Development Bank (ADB) (2012a). Kingdom of Cambodia: Strengthening technical and vocational education and training Project II (TASF). Available at http://www.adb.org/ projects/40555-012/main [Accessed on 30 September 2015].

Asian Development Bank (ADB) (2012b). Philippines: Technical education and skills development project and fund for technical education and skills development. Available at http://www. adb.org/sites/default/files/evaluation-document/36063/files/pvr-220.pdf [Accessed on 30 September 2015].

Asian Development Bank (ADB) (2014). Technical and Vocational Education and Training in the Socialist Republic of Vietnam: An assessment. Available at http://www.adb.org/publications/ technical-and-vocational-education-and-training-socialist-republic-viet-nam-assessment [Accessed on 30 September 2015].

Association of Southeast Asian Nations (ASEAN) (2014). ASEAN Enhances Mobility of Skilled Labour through Qualifications Reference Framework. Available at http://www.asean.org/news/aseansecretariat-news/item/asean-enhances-mobility-of-skilled-labour-through-qualificationsreference-framework [Accessed on 30 September 2015].

Cappelli, P. (2015). Skills Gaps, Skills Shortages, and Skill Mismatches: Evidence and arguments for the United States. ILR Review, 68(2), pp. 251-290.

Chen, L., Mourshed M., and Grant, A. (2013). The $\$ 250$ Billion Question: Can China close the skills gap? Available at http://mckinseyonsociety.com/downloads/reports/Education/china-skillsgap.pdf [Accessed on 30 September 2015].

Hanushek, E. A., and Woessmann, L. (2015). Universal Basic Skills: What countries stand to gain. OECD. Available at http://dx.doi.org/10.1787/9789264234833-en [Accessed on 30 September 2015].

Heckman, J. J., and Kautz, T. (2013). Fostering and Measuring Skills: Interventions that improve character and cognition. NBER Working Paper, No. 19656. National Bureau of Economic Research.

Heckman, J. J., Stixrud, J. and Urzua, S. (2006). The Effects of Cognitive and Noncognitive Abilities on abor Market Outcomes and Social Behaviour. Journal of Labor Economics, 26 (3), pp.411-482.

International Labour Office (ILO) (2012). World of Work Report 2012: Better jobs for a better economy. Available at http://www.ilo.org/wcmsp5/groups/public/@dgreports/@dcomm/@publ/ documents/publication/wcms_179453.pdf [Accessed on 30 September 2015].

International Labour Office (ILO) (2014a) World of Work Report 2014: Developing with jobs. Available at http://www.ilo.org/wcmsp5/groups/public/---dgreports/---dcomm/documents/publication/ wcms_243961.pdf [Accessed on 30 September 2015].

International Labour Office (ILO) (2014b). Assessment Study of Technical and Vocational Education and Training (TVET) in Myanmar. Available at http://apskills.ilo.org/resources/assessment- 
study-of-technical-and-vocational-education-and-training-tvet-in-myanmar/at_download/file1 [Accessed on 30 September 2015].

International Labour Office (ILO) (2015). World Employment and Social Outlook: Trends 2015. Available at http://www.ilo.org/global/research/global-reports/weso/2015/lang--en/index. htm [Accessed on 30 September 2015].

Maclean, R., Jagannathan, S. and Sarvi, J. (2013). Skills Development for Inclusive and Sustainable Growth in Developing Countries in the Asia-Pacific. The Netherlands: Springer.

Martinez-Fernandez, C. and Choi, K. (2012). An overview of skills development pathways in Asia. Available at http://www.oecd.org/cfe/leed/Skills\%20Development\%20Pathways\%20in\%20 Asia_FINAL\%20VERSION.pdf [Accessed 30 September 2015].

Martinez-Fernandez, C. and Weyman, T. (2014). Skills Development for the Knowledge Economy in Asia: Some conclusions from the OECD experience. Prospects, 44, pp.249-266.

McKinsey Global Institute (2012). Education to Employment: Designing a system that works. Report prepared by M. Mourshed, D. Farrell and D. Barton. Available at http://mckinseyonsociety. com/downloads/reports/Education/Education-to-Employment_FINAL.pdf [Accessed on 30 September 2015].

Molnar, M. and Koen, V. (2015). Providing the Right Skills to All in China. OECD Economics Department Working Paper No. 1219. Available at http://www.keepeek.com/Digital-Asset-Management/ oecd/economics/providing-the-right-skills-to-all-in-china_5js1j18g4tlx-en\#page1 [Accessed on 30 September 2015].

Naidu-Ghelani, R. (2015). Asean Economic Growth 'to outdo EU'. Available at http://www.bbc.com/ news/business-32387376 [Accessed on 30 September 2015].

Organisation for Economic and Cultural Development (OECD) (2012a). Better Skills, Better Jobs, Better Lives: A strategic approach to skills policies. Available at http://dx.doi. org/10.1787/9789264177338-en [Accessed on 30 September 2015].

Organisation for Economic and Cultural Development (OECD) (2012b). Skills Development Pathways in Asia: Employment and skills strategies in Southeast Asia initiative. Available at http://www. oecd.org/cfe/leed/Skills\%20Development\%20Pathways\%20in\%20Asia_FINAL\%20VERSION. pdf [Accessed on 30 September 2015].

Organisation for Economic and Cultural Development (OECD) (2014a). Skills Beyond School: Synthesis report. OECD Reviews of Vocational Education and Training. Available at http://www.oecd. org/edu/skills-beyond-school/Skills-Beyond-School-Synthesis-Report.pdf [Accessed on 30 September 2015].

Organisation for Economic and Cultural Development (OECD) (2014b). PISA 2012 Results in Focus: What 15 year olds know and what they can do with what they know. Available at http://www. oecd.org/pisa/keyfindings/pisa-2012-results-overview.pdf [Accessed on 30 September 2015].

Organisation for Economic and Cultural Development (OECD) (2015). Skills for Social Progress: The power of social and emotional skills. Available at http://dx.doi.org/10.1787/9789264226159en [Accessed on 30 September 2015].

Organisation for Economic and Cultural Development (OECD) and Asian Development Bank (ADB) (2015). Education in Indonesia: Rising to the challenge. Reviews of National Policies for Education. Available at http://dx.doi.org/10.1787/9789264230750-en [Accessed on 30 September 2015].

Panth, B. (2014). Skills Development for Employability and Inclusive Growth: Policy dilemmas and priorities in South Asia. Prospects, 44, pp.249-266.

Rodrik, D. (2013). The Past, the Present and the Future of Economic Growth. Global Citizen Foundation Working Paper 1. Available at https://www.sss.ias.edu/files/pdfs/Rodrik/Research/GCF_Rodrikworking-paper-1_-6-24-13.pdf [Accessed on 30 September 2015].

United Nations Educational Scientific and Cultural Organization (UNESCO) (2011). Building Skills in the Informal Sector. Background paper prepared for the Education for All Global Monitoring 
Report 2012. Available at http://www.unesco.org/new/fileadmin/MULTIMEDIA/HQ/ED/pdf/ gmr2012-ED-EFA-MRT-PI-08.pdf [Accessed on 30 September 2015].

United Nations Educational Scientific and Cultural Organization (UNESCO) (2012). Youth and Skills: Putting education to work. EFA Global Monitoring Report. Available at http://unesdoc.unesco. org/images/0021/002180/218003e.pdf [Accessed on 30 September 2015].

United Nations Educational Scientific and Cultural Organization (UNESCO) (2013). Global National Qualifications Framework Inventory. Available at http://www.cedefop.europa.eu/fr/ publications-and-resources/publications/2211 [Accessed on 30 September 2015].

Valiente, O. (2014). The OECD Skills Strategy and the Education Agenda for Development. International Journal of Educational Development, 39, pp.40-48.

World Bank (2010). Stepping up Skills for More Jobs and Higher Productivity. Available at http:// documents.worldbank.org/curated/en/2010/06/12515032/stepping-up-skills-more-jobshigher-productivity [Accessed on 30 September 2015].

World Bank (2012a). Singapore: Workforce development. SABER Country Report. Available at http:// wbgfiles.worldbank.org/documents/hdn/ed/saber/supporting_doc/CountryReports/WFD/ SABER_WfD_Vietnam_CR_Final_2012.pdf [Accessed on 30 September 2015].

World Bank (2012b). Vietnam: Workforce development. SABER Country Report. Available at http:// wbgfiles.worldbank.org/documents/hdn/ed/saber/supporting_doc/CountryReports/WFD/ SABER_WfD_Singapore_Multiyear_CR_2012.pdf [Accessed on 30 September 2015].

World Bank (2013a). World Development Report: Jobs. Available at http://siteresources.worldbank. org/EXTNWDR2013/Resources/8258024-1320950747192/8260293-1322665883147/ WDR_2013_Report.pdf [Accessed on 30 September 2015].

World Bank (2013b). Malaysia: Workforce development. SABER Country Report. Available at http:// wbgfiles.worldbank.org/documents/hdn/ed/saber/supporting_doc/CountryReports/WFD/ SABER_WfD_Malaysia_CR_Final_2013.pdf [Accessed on 30 September 2015].

World Bank (2014a). Skilling up Vietnam: Preparing the workforce for a modern market economy. Available at http://www.worldbank.org/en/country/vietnam/publication/vietnamdevelopment-report2014-skilling-up-vietnam-preparing-the-workforce-for-a-modern-marketeconomy [Accessed on 30 September 2015].

World Bank (2014b). Lao Development Report 2014. Available from http://www.worldbank.org/en/ country/lao/publication/lao-pdr-development-report-2014 [Accessed on 30 September 2015].

World Bank (2014c). World Bank Group: New open data tool helps countries compare progress on education. Available from http://www.worldbank.org/en/news/press-release/2014/01/21/ world-bank-group-new-open-data-tool-helps-countries-compare-progress-on-education [Accessed on 30 September 2015].

World Economic Forum (WEF) (2014). Matching Skills and Labour Market Needs: Building social partnerships for better skills and better jobs. Available at http://www.weforum.org/reports/ matching-skills-and-labour-market-needs-building-social-partnerships-better-skills-and-better skills and better jobs [Accessed on 30 September 2015]. 